\title{
Production of Alien Addition Lines in Polyploid Bunching Onion (Allium fistulosum) Carrying 1A Chromosome(s) of Shallot (Allium cepa) and Their Application to Breeding for a New Vitamin C-Rich Vegetable
}

\author{
Shigenori Yaguchi \\ The United Graduated School of Agricultural Sciences, Tottori University, 4-101 Koyama-minami, \\ Tottori 680-8553, Japan \\ Masanori Atarashi, Masatoshi Iwai ${ }^{1}$, and Shin-ichi Masuzaki \\ Department of Biological and Environmental Sciences, Faculty of Agriculture, Yamaguchi University, \\ 1677-1 Yoshida, Yamaguchi-shi, Yamaguchi 753-8515, Japan \\ Naoki Yamauchi and Masayoshi Shigyo
The United Graduated School of Agricultural Sciences, Tottori University, 4-101 Koyama-minami,
Tottori 680-8553, Japan and Department of Biological; and Environmental Sciences, Faculty of
Agriculture, Yamaguchi University, 1677-1 Yoshida, Yamaguchi-shi, Yamaguchi 753-8515, Japan
}

AdDitional INDEX wORDs. alien monosomic addition, ascorbic acid, disomic addition, leaf vegetable, tetraploid

Abstract. Eight Allium fistulosum L.-Allium cepa L. Aggregatum group (shallot) monosomic addition lines $(2 n=17$, $\mathrm{FF}+1 \mathrm{~A}-\mathrm{FF}+\mathbf{8 A}$ ) have been useful in revealing the effects of single alien chromosomes from $\mathrm{A}$. cepa on the production of L-ascorbic acid in the leaf tissue of $A$. fistulosum. In this study, the determination of ascorbic acid content revealed that the incorporation of alien chromosome $1 \mathrm{~A}$ into a diploid background of $A$. fistulosum increased the internal ascorbic acid content of the leaf blade tissue. We produced a 1 A disomic addition in the tetraploid of $A$. fistulosum $(2 n=34)$ and demonstrated high-frequency transfer of the alien chromosome in crosses with $A$. fistulosum. Five plants of the $1 \mathrm{~A}$ disomic additions were regenerated via apical meristem culture of the $\mathrm{FF}+1 \mathrm{~A}$ on a Murashige and Skoog medium containing colchicine. These 1A disomic additions showed partial fertility for female and male gametes. Most of the progenies from selfing of the 1A disomic additions and reciprocal crossing with $A$. fistulosum possessed chromosome $1 \mathrm{~A}$. Interestingly, $64 \%$ (18 of 28$)$ of the plants obtained from the reciprocal crosses were $1 \mathrm{~A}$ monosomic additions in a triploid background of $A$. fistulosum. These monosomic additions were more vigorous and vitamin C-rich than euploid plants of $\boldsymbol{A}$. fistulosum.

Japanese bunching onion (Allium fistulosum) is one of the most important vegetable crops in eastern Asia, especially in Japan, Korea, and China (Inden and Asahira, 1990). Allium fistulosum is a perennial plant, grown commercially as an annual or a biennial, and usually propagated by seed. There are basically two types of $A$. fistulosum in Japan: Nebuka-negi (white-leaf sheath type) and Ha-negi (green-leaf type) (Yakuwa, 2006). The Ha-negi cultivars are mainly grown in the southern part of Japan for the production of their green leaf blades, which are used in salads, or as herbs to flavor soups and other foods. The chemical composition of the white leaf sheath and green leaf blades differs; the green leaf types contain higher levels of $\beta$-carotene and vitamins B1, B2, and C. However, the

Received for publication 19 Nov. 2007. Accepted for publication 18 Jan. 2008 This work was partly supported by "Knowledge Cluster Initiative", Ministry of Education, Culture, Sports, Science and Technology, Japan.

We would like to thank Michael J. Havey of Agricultural Research Service (U.S. Department of Agriculture and University of Wisconsin) for critically reviewing this manuscript.

${ }^{1}$ Current address: Shippo Seed Co., Ltd., 2412-2 Okamoto, Toyonaka-cho, Mitoyo-shi, Kagawa 769-1507, Japan.

${ }^{2}$ Corresponding author. E-mail: shigyo@yamaguchi-u.ac.jp. contents of each vitamin in the green-leaf $A$. fistulosum are lower than those of other vitamin-rich vegetables and it is therefore desirable to increase vitamin contents in A. fistulosum.

A complete set of $A$. fistulosum-Allium cepa Aggregatum group monosomic addition lines $(2 n=17, \mathrm{FF}+1 \mathrm{~A}-\mathrm{FF}+8 \mathrm{~A})$ was established in our previous study (Shigyo et al., 1996). This series displays morphological and physiological characteristics that are different from those of the A. fistulosum recurrent parent (Shigyo et al., 1997a). Unfortunately, the direct utilization of the monosomic additions for breeding purposes is difficult because of chromosomal instability in selfed and backcrossed progenies (Shigyo et al., 1999a). Self-pollination or colchicine treatment can be used to produce a stable, nonsegregating disomic addition from a monosomic addition. The frequency of disomic additions in the selfed progeny of monosomic additions in diploid Allium L. species was very low compared with those recorded at the $6 x$ level of wheat [Triticum aestivum (L.) Thell.; Shigyo et al., 2003]. Consequently, only one successful attempt has thus far been reported for the generation of $A$. fistulosum-8A disomic additions (Shigyo et al., 2003).

In the present study, we attempted to breed for increased vitamin C (ascorbic acid) content in A. fistulosum via the 
chromosome doubling of an ascorbic acid-rich A. fistulosumshallot monosomic addition line by 1) determination of the ascorbic acid content in a complete set of monosomic addition lines, 2) colchicine treatment for the chromosome doubling of the ascorbic acid-rich monosomic additions, 3) confirmation of the ploidy levels in colchicine-treated plants, 4) evaluation of ability for generative propagation in 1A disomic addition in tetraploid of A. fistulosum, and 5) observation of several agronomic traits, including the ascorbic acid content of the leaf blade in the progeny of the 1A disomic addition.

\section{Materials and Methods}

Plant materials. The plant materials were a complete set of A. fistulosum-A. cepa monosomic additions $(2 n=2 x+1=17$, $\mathrm{FF}+1 \mathrm{~A}-\mathrm{FF}+8 \mathrm{~A})$ and control plants, the japanese bunching onion (A. fistulosum 'Kujyo-hoso', $2 n=2 x=16$, FF) and shallot ( $A$. cepa Aggregatum group 'Chiang mai', $2 n=2 x=16$, AA), and colchicine-treated derivatives of FF+1A $(2 n=4 x+$ $2=34$, etc.). Selfed and backcrossed progenies using $1 \mathrm{~A}$ disomic additions were observed for agronomic traits described below.

AsCorbiC ACID EXTRACTION AND ITS DETERmination. Ascorbic acid from fresh leaf blades $(2.5 \mathrm{~g})$ was extracted with $10 \mathrm{~mL}$ of 10\% metaphosphoric acid (final concentration, 2\% metaphosphoric acid) and $37.5 \mathrm{~mL}$ of distilled water. The extract was filtered by passing through a \#2 filter paper (ADVANTEC, Tokyo). After proper dilution with a $2 \%$ metaphosphoric acid solution, the ascorbic acid concentrations in the filtrate was measured by the 2,4-dinitrophenylhydrazine method (Roe et al., 1948) with minor modifications. Two drops of $0.2 \%$ 2,6-dichloroindophenol sodium solution was added to $1-\mathrm{mL}$ aliquots of filtrates. One-half was used for the assay of ascorbic acid and the other one served as blank control. A 2-mL solution of $2 \%$ metaphosphoric acid and $2 \%$ thiourea was added to both fractions. A fraction of the assay was mixed with $0.5 \mathrm{~mL}$ of $2 \%$ 2,4-dinitrophenylhydrazine in concentrated $\mathrm{H}_{2} \mathrm{SO}_{4}$ freshly diluted $1: 3$ in water. This mixture was incubated for $70 \mathrm{~min}$ at $50{ }^{\circ} \mathrm{C}$, and then chilled and mixed with $2.5 \mathrm{~mL}$ of $85 \%$ $\mathrm{H}_{2} \mathrm{SO}_{4}$. The blank was incubated for $70 \mathrm{~min}$ at $50{ }^{\circ} \mathrm{C}$, and then chilled and mixed with $0.5 \mathrm{~mL}$ of $2 \%$ 2,4-dinitrophenylhydrazine. This blank was mixed with $2.5 \mathrm{~mL}$ of $85 \% \mathrm{H}_{2} \mathrm{SO}_{4}$. Ascorbic acid content was quantified with the absorbance at $530 \mathrm{~nm}$ on a U-2001 spectrophotometer (Hitachi High-Technologies Corp, Tokyo). The determination was conducted once per month from Jan. 2002 to Dec. 2003.

Chromosome doubling. Explants of $\mathrm{FF}+1 \mathrm{~A}$ were prepared for chromosome doubling by trimming the roots and cutting the leaves about $30 \mathrm{~mm}$ above the base. Shoots (about $10 \mathrm{~mm}$ long) with basal plates were dissected from the other tissues, sterilized for $15 \mathrm{~min}$ in a $20 \%$ hypochlorous acid solution with a drop of Tween 20 (Wako Pure Chemical Industries, Ltd., Osaka, Japan), and then rinsed three times with sterile distilled water. From these sterilized shoots, shoot tip explants less than $1 \mathrm{~mm}$ long were aseptically excised and transferred to a Murashige and Skoog (MS) medium (Murashige and Skoog, 1962) supplemented with $0.05 \%(\mathrm{w} / \mathrm{v})$ colchicine, $2 \%(\mathrm{w} / \mathrm{v})$ dimethyl sulphoxide, and 3\% (w/v) sucrose and solidified with $0.8 \%(\mathrm{w} / \mathrm{v})$ agar at $\mathrm{pH} 5.8$. After treatment for $4 \mathrm{~d}$ in the dark, the explants were transferred to MS medium without colchicine and dimethyl sulphoxide for 3 months. Subcultures were maintained at $25{ }^{\circ} \mathrm{C}$ with a daylength of $18 \mathrm{~h}$. Plantlets of established colchicine-treated plants were transplanted to a glasshouse.

Ploidy analyses. The ploidy of roots derived from the germ layer (L-III) was determined by the number of chromosomes in a root tip cell: diploid with $2 n=17$ and tetraploid with $2 n=34$. The somatic chromosomes of root tips in the colchicine-treated plants were observed by Feulgen nuclear staining, followed by the squash method according to Shigyo et al. (1999a). The ploidy of the mesophyll tissue (L-II) was determined by a flow cytometric analysis with a PA flow cytometer (Partec, Münster, Germany). Assays used colchicine-treated plants and FF+1A as the control. Between 8 and 10 months after sowing, a young leaf blade was collected from plants, cut with a razorblade, and placed in a 4',6-diamino-2-phenylindole staining solution (Partec) with a leaf blade of Allium vavilovii M. Pop. Et Vved. [32.8 pg of DNA per nuclear DNA (2C); Ricroch et al., 2005] as the internal standard. The fluorescence intensity at the G1 peak was measured, and extra chromosome index [EI (the mean fluorescence intensity of the test plant in relation to the internal standard and expressed as a percentage) as previously described (Shigyo et al., 2003)] was calculated for colchicine-treated plants. The nuclear DNA content of test plant was calculated according to the DNA content of $A$. vavilovii. Measurements were repeated three times for each plant. The ploidy of the epidermis (L-I) was classified by the guard cell length. Adaniya and Ardian (1994) classified diploids of A. fistulosum at $44 \mu \mathrm{m}$ (range: $38.0-50.7 \mu \mathrm{m}$ ) and tetraploids at $54 \mu \mathrm{m}$ (range: $46.4-$ $63.3 \mu \mathrm{m})$. The assay plants included several plants determined to be tetraploids by L-III and L-II tissue analyses with FF+1 A as the control.

OBSERVATION OF MICROSPOROGENESIS. Flower buds of 1A disomic addition lines were fixed at different developmental stages in a mixture of acetic acid and ethyl alcohol (1:3). The microspores were observed by the smear method with acetocarmine and were photographed under an optical microscope according to Yamashita (1999).

Pollen fertility Test. The anthers from two 1A disomic additions were collected for the chromosome observation and were pollen fertility tested before dehiscence. Pollen grains were stained with acetocarmine by the smear method, and pollen fertility was evaluated according to pollen morphology and stainability following the method of Shigyo et al. (1999b). About 2000 pollen grains per plant were observed. Pollen germination was scored after $2 \mathrm{~h}$ on a medium consisting of $1 \%$ $(\mathrm{w} / \mathrm{v})$ agar and $10 \%(\mathrm{w} / \mathrm{v})$ sucrose and was photographed under an optical microscope.

SEED PRODUCTION AND ADDitional CHROMOSOME TRANSMISSION TEST. One 1A disomic addition displayed a vigorous growth (No. 23-1) was self-pollinated to obtain the $\mathrm{S}_{1}$ generation and reciprocally crossed with 'Kujyo-hoso' to produce the $\mathrm{BC}_{1}$ generations. All procedures for crossing were conducted according to Hang et al. (2004b). The capability of seed set was evaluated by the percentage of ovules that developed into seeds and the seed germination rate, as described in our previous study (Shigyo et al., 2003). Seeds were sown on MS medium without hormones and were cultured at $25{ }^{\circ} \mathrm{C}$ in the dark. The germinated seeds were kept at $25^{\circ} \mathrm{C}$ under a $12-\mathrm{h}$ photoperiod; the seedlings were eventually transplanted into pots. The chromosomes in the root tips of progenies were stained with the standard Feulgen squash method and were observed and photographed under an optical microscope. The leucine aminopeptidase (LAP) isozyme gene locus located on 
chromosome 1A (Lap-1 on 1A, described by Shigyo et al., 1995) was analyzed for the seedlings. All the procedures for the LAP isozyme analysis were conducted according to Shigyo et al. (1995).

MORPHOLOGICAL CHARACTERIZATION AND DETERMINATION OF ASCORBIC ACID CONTENTS IN 1A DISOMIC ADDITION AND THEIR PRoGENIES. The leaf length, the leaf sheath diameter, and the ascorbic acid content of the $1 \mathrm{~A}$ disomic additions and their progenies were measured in Aug. 2007.

Statistical analysis. Data of the ascorbic acid content, EI, nuclear DNA content, and guard cell length were used for oneway analyses of variance (ANOVA). When needed, Dunnett's multiple test and Tukey's multiple test were used. Statistical analyses were performed using SPSS with advanced models (version 11.5; SPSS Japan, Tokyo).

\section{Results}

DETERMination OF ASCORBIC ACID CONTENTS IN MONOSOMIC ADDITIONS. The contents of ascorbic acid in A. fistulosum (the control) varied from 31.5 to $96.4 \mathrm{mg} / 100 \mathrm{~g}$ fresh weight (FW) and were averaged on $62.5 \mathrm{mg} / 100 \mathrm{~g} \mathrm{FW}$ (Fig. 1). Ascorbic acid contents of shallot were similar to that of A. fistulosum in winter. In shallot, the lack of data in summer was caused by dormancy with a bulb formation. The seasonal change of the ascorbic acid contents in A. fistulosum showed that the contents stayed at a high level in winter, decreased from spring to summer, and then increased from autumn to winter. The ascorbic acid accumulations in all the monosomic additions showed the same tendency with $A$. fistulosum. The contents of the ascorbic acid in FF+1A and FF+2A (average, 93.1 and $90.5 \mathrm{mg} / 100 \mathrm{~g} \mathrm{FW}$, respectively) were higher than those in A. fistulosum throughout the 2-year study. FF+8A also accumulated a high volume of the ascorbic acid $(76.4 \mathrm{mg} / 100 \mathrm{~g} \mathrm{FW})$. These monosomic addition lines showed that the alien chromosomes, such as $1 \mathrm{~A}, 2 \mathrm{~A}$, and $8 \mathrm{~A}$, caused the value of the ascorbic acid to increase in the winter. The contents of the other three monosomic additions, $\mathrm{FF}+3 \mathrm{~A}, \mathrm{FF}+5 \mathrm{~A}$, and $\mathrm{FF}+7 \mathrm{~A}$, were slightly higher than that of $A$. fistulosum. The remaining two monosomic additions, $\mathrm{FF}+4 \mathrm{~A}$ and $\mathrm{FF}+6 \mathrm{~A}$, showed almost the same level of the ascorbic acid contents as that of A. fistulosum. One-way ANOVA revealed a significant difference (at the 1\% level) in the monthly contents of the ascorbic acid $(F=15.92)$ as well as among plant materials $(F=16.53)$. Dunnett's test showed significant differences between the three monosomic additions ( $\mathrm{FF}+1 \mathrm{~A}, \mathrm{FF}+2 \mathrm{~A}$, and $\mathrm{FF}+8 \mathrm{~A})$ and the control (Fig. 1). This result allowed us to conclude that anonymous genes related to upregulating ascorbic acid production are located on three distinct shallot chromosomes 1A, 2A, and 8A.

Chromosome doubling and ploidy analyses. Colchicine treatments of 90 explants of $\mathrm{FF}+1 \mathrm{~A}$ produced 29 regenerated plants. Representative data from nine of these plants is summarized in Table 1. Chromosome counts in root-tip cells revealed that seven plants were doubled in L-III $(2 n=4 x+2=$ 34, Fig. 2A) and 18 plants were not doubled $(2 n=2 x+1=17)$. The remaining four were cytochimeral plants. Flow cytometric analyses of the regenerated plants showed bimodal peaks when the test plants measured together with the internal standard for G1- and G2-phase nuclei. ANOVA revealed a significant difference in the EI among regenerated plants at the $1 \%$ level. The nuclear DNA amount from 46.8 to $48.0 \mathrm{pg}$ was scored as tetraploid, and one from 23.8 to $24.8 \mathrm{pg}$ as diploid. In

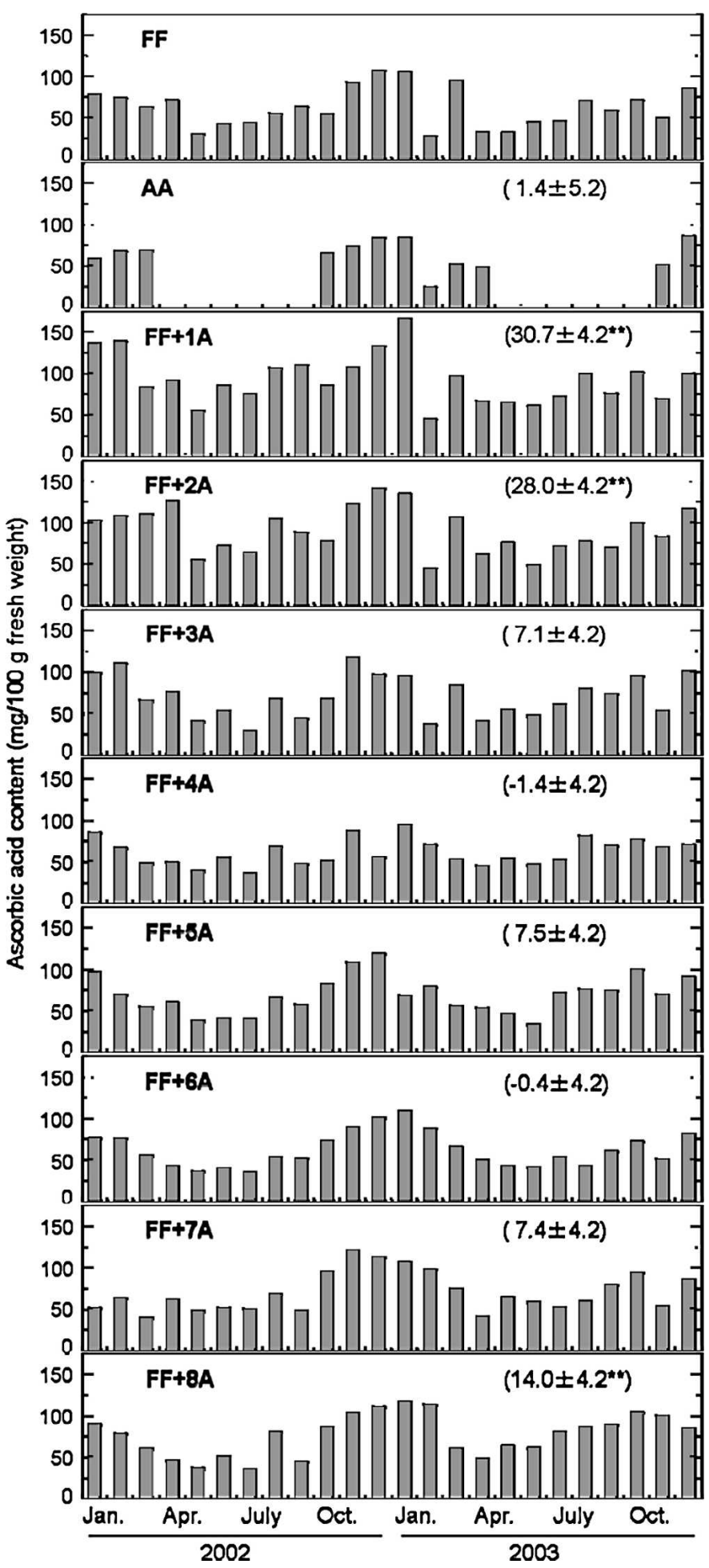

Fig. 1. The year-round variations of ascorbic acid content in a complete set of monosomic additions ( $\mathrm{FF}+1 \mathrm{~A}-\mathrm{FF}+8 \mathrm{~A})$, Allium fistulosum (FF), and shallot (AA). Values in parentheses show mean difference of ascorbic acid content between A. fistulosum and each plant material with mean \pm SE. Dunnett's multiple test was used for mean separation. ${ }^{* *}$ indicates significant difference at $P \leq 0.01$.

agreement with the L-III results, the L-II layer of seven plants were doubled, 18 plants were not doubled, and the remaining four were cytochimeral. The guard cell length was observed in seven plants scored as tetraploid in L-III and L-II. The mean 
Table 1. Estimation of ploidy levels in the three germ layers of colchicine-treated nine representative plants and $1 \mathrm{~A}$ monosomic addition $(\mathrm{FF}+1 \mathrm{~A})$.

\begin{tabular}{|c|c|c|c|c|c|c|}
\hline \multirow{3}{*}{$\begin{array}{l}\text { Plant } \\
\text { number }\end{array}$} & \multicolumn{3}{|c|}{ Ploidy of roots (L-III) } & \multicolumn{2}{|c|}{ Ploidy of mesophyll tissues (L-II) } & \multirow{3}{*}{$\begin{array}{c}\text { Ploidy of } \\
\text { epidermis }(\mathrm{L}-\mathrm{I}) \\
\text { Diameter } \\
\text { of guard } \\
\text { cells }(\mu \mathrm{m})\end{array}$} \\
\hline & \multirow{2}{*}{$\begin{array}{c}\text { Cells } \\
\text { observed } \\
\text { (no.) } \\
\end{array}$} & \multicolumn{2}{|c|}{ Chromosomes (no.) } & \multirow{2}{*}{$\begin{array}{c}\text { Extra } \\
\text { chromosome } \\
\text { index }\end{array}$} & \multirow{2}{*}{$\begin{array}{l}\text { Nuclear DNA } \\
\text { content (pg) }\end{array}$} & \\
\hline & & 17 & 34 & & & \\
\hline No. 1 & 19 & 19 & 0 & $0.73 \mathrm{a}^{\mathrm{z}}$ & $23.81 \mathrm{a}^{\mathrm{z}}$ & - \\
\hline No. 6 & 60 & 35 & 25 & $\begin{array}{l}0.73 \mathrm{a} \\
1.44 \mathrm{~b}\end{array}$ & $\begin{array}{l}23.78 \mathrm{a} \\
47.23 \mathrm{~b}\end{array}$ & - \\
\hline No. $11-1^{y}$ & 34 & 0 & 34 & $1.46 \mathrm{~b}$ & $48.02 \mathrm{~b}$ & $51.2 \mathrm{~d}^{\mathrm{z}}$ \\
\hline No. 14-1 & 30 & 0 & 30 & $1.44 \mathrm{~b}$ & $47.30 \mathrm{~b}$ & $40.2 \mathrm{~b}$ \\
\hline No. 21 & 38 & 0 & 38 & $1.45 \mathrm{~b}$ & $47.49 \mathrm{~b}$ & $39.6 \mathrm{ab}$ \\
\hline No. $23-1^{y}$ & 36 & 0 & 36 & $1.45 \mathrm{~b}$ & $47.46 \mathrm{~b}$ & $50.1 \mathrm{~cd}$ \\
\hline No. $23-2^{y}$ & 31 & 0 & 31 & $1.43 \mathrm{~b}$ & $46.81 \mathrm{~b}$ & $50.1 \mathrm{~cd}$ \\
\hline No. $23-3^{y}$ & 30 & 0 & 30 & $1.45 \mathrm{~b}$ & $47.63 \mathrm{~b}$ & $48.5 \mathrm{c}$ \\
\hline No. $23-5^{y}$ & 32 & 0 & 32 & $1.45 \mathrm{~b}$ & $47.66 \mathrm{~b}$ & $50.0 \mathrm{~cd}$ \\
\hline $\mathrm{FF}+1 \mathrm{~A}$ & 30 & 30 & 0 & $0.73 \mathrm{a}$ & $23.94 \mathrm{a}$ & $38.3 \mathrm{a}$ \\
\hline
\end{tabular}

${ }^{\mathrm{z}}$ Mean separation within each column by Tukey's multiple test at $P \leq 0.01$.

yThe footnotes indicate the plants of 1A disomic addition.

values of the guard cell length varied from 39.6 to $51.2 \mathrm{pg}$ (Table 1). ANOVA revealed a significant difference in the guard cell length among regenerated plants at the $1 \%$ level. Two different groups of histograms of the guard cell length were obtained because of the peak positions of their histograms (data not shown). No. 14-1 and No. 21 were centered on $\approx 40$ $\mu \mathrm{m}$, and the remaining five (No. 11-1, No. 23-1, No. 23-2, No. 23-3, and No. 23-5) were centered on about $50 \mu \mathrm{m}$. The mean value of $\mathrm{FF}+1 \mathrm{~A}$ as a control was $38.3 \mu \mathrm{m}$. From these results,
No. 11-1, No. 23-1, No. 23-2, No. 23-3, and No. 23-5 were classified as tetraploids in L-I, and No. 14-1 and No. 21 were scored as diploids in L-I. Consequently, five plants of the $1 \mathrm{~A}$ disomic addition in the tetraploid of A. fistulosum were identified.

OBSERVATION OF MICROSPOROGENESIS. The process of microsporogenesis was evaluated in two (No. 23-1 and No. 23-5) of the five 1A disomic additions. During meiosis, the percentages of normal microspore formation were $\approx 76 \%$ after the first and second anaphases (data not shown, Fig. 2B-D). Seventeen chromosomes were observed in $88 \%$ of the pollens $(n=2 x+1)$, and 34 chromosomes were observed in the $12 \%$ remaining pollens $(n=4 x+2$, Table 2$)$. The presence of 34 chromosomes was likely from unreduced gametes.

Pollen fertility test. Pollen of A. fistulosum showed 97\% stainability and $54 \%$ germinability (Table 2 ). These rates were lower for the monosomic addition $\mathrm{FF}+1 \mathrm{~A}$ at $79 \%$ stainability and $30 \%$ germinability. In the $1 \mathrm{~A}$ disomic additions, $50 \%$ of the pollen grains showed stainability and $8 \%$ germinated (Table 2 and Fig. 2E).

SEED PROdUCTION AND ADdiTIONAL CHROMOSOME TRANSMISSION TEST. Seed fertility of the backcross when the disomic was used as the female was higher $(10.9 \%)$ than from
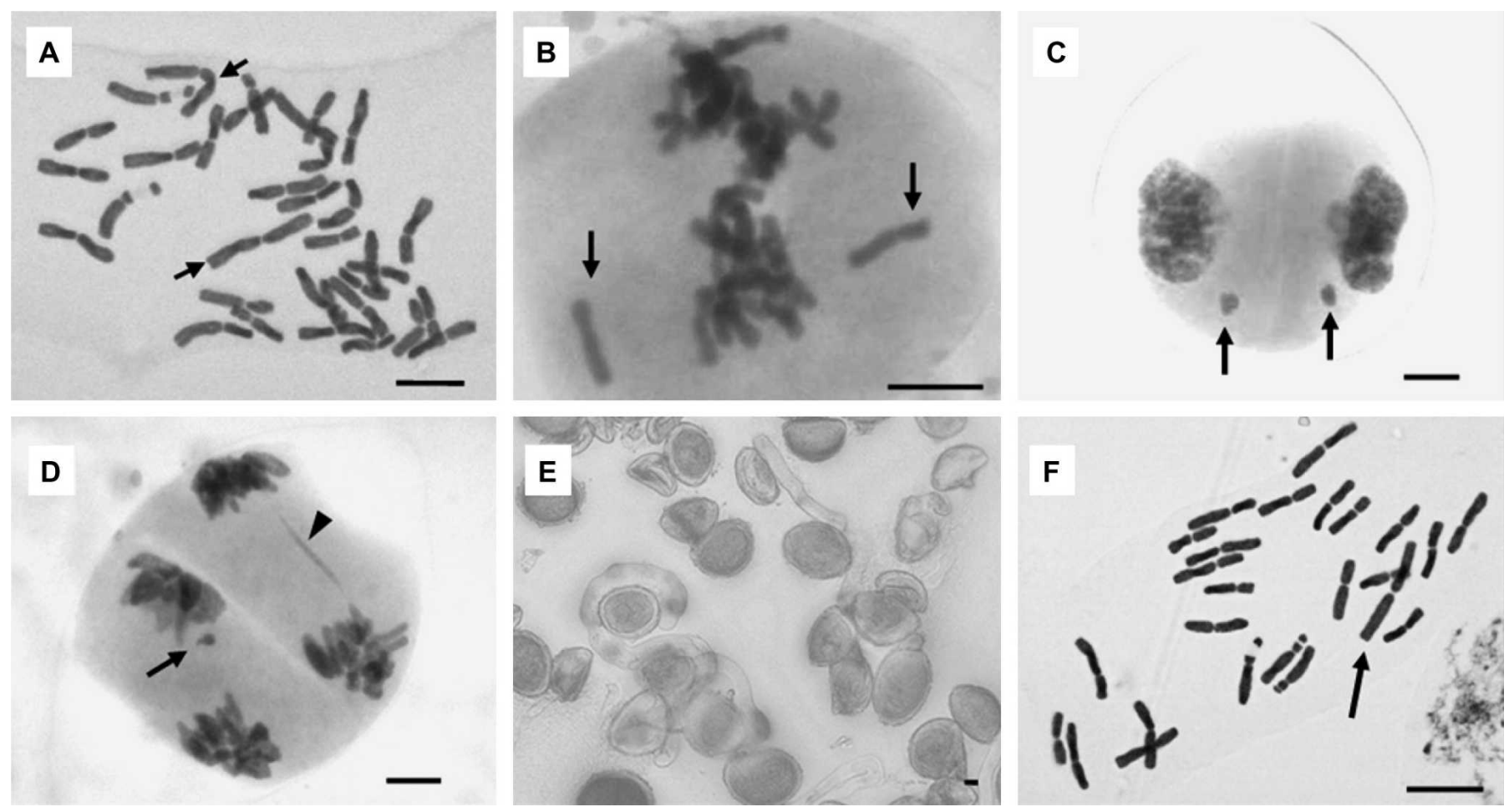

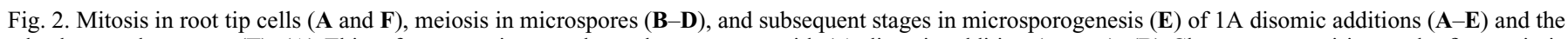
backcrossed progeny (F). (A) Thirty-four somatic metaphase chromosomes with 1A disomic addition (arrows). (B) Chromosome pairing at the first meiotic metaphase with the univalent chromosomes (arrows). (C) Chromosome pairing at the first meiotic metaphase with the lagging chromosomes (arrows). (D) Chromosome pairing at the second meiotic telophase with the lagging chromosome (arrow) and the chromosome bridge (arrow head). (E) Pollen germination with 1 A disomic addition. (F) Twenty-five somatic metaphase chromosomes with 1 A monosomic addition (arrow) in a triploid background of $A$. fistulosum $(2 n=3 x+$ $1=25)$. Scale bar $=10 \mu \mathrm{m}$. 
the disomic self $(2.2 \%)$ and its reciprocal backcross $(1.0 \%$; Table 3). The germinability of the $\mathrm{S}_{1}$ seed (4.8\%) was lower than that of the $\mathrm{BC}_{1}$ progenies $(38.2 \%)$. Somatic chromosome numbers and the Lap $-1^{a}$ zymograms revealed successful trans- mission of chromosome $1 \mathrm{~A}$ into all the $\mathrm{S}_{1}$ and $\mathrm{BC}_{1}$ progenies from the $1 \mathrm{~A}$ disomic addition (Table 4). However, variations in chromosome numbers were detected in every cross. Importantly, $64 \%$ of the plants obtained from the reciprocal crossings

Table 2. Number of chromosomes in microspores at pollen mitosis and pollen fertility in $1 \mathrm{~A}$ disomic additions (FFFF+1A1A).

\begin{tabular}{|c|c|c|c|c|c|c|}
\hline \multirow[b]{3}{*}{ Plant materials } & \multicolumn{4}{|c|}{ Pollen mitosis } & \multirow{2}{*}{\multicolumn{2}{|c|}{ Pollen fertility }} \\
\hline & \multicolumn{4}{|c|}{ Chromosomes (no.) } & & \\
\hline & 8 & 9 & 17 & 34 & Stainability & Germinability \\
\hline FFFF+1A1A (No. 23-1) & - & - & $43(86.0)^{z}$ & $7(14.0)^{z}$ & $923 / 2018^{y}(45.7)^{z}$ & $20 / 310^{x}(6.5)^{z}$ \\
\hline Allium fistulosum ${ }^{\mathrm{w}}$ & - & - & - & - & 2031/2099 (96.8) & $173 / 318(54.4)$ \\
\hline 1A monosomic addition ${ }^{\mathrm{v}}$ & $172(81.9)^{z}$ & $38(18.1)^{\mathrm{z}}$ & - & - & $1723 / 2175(79.2)$ & $106 / 351(30.2)$ \\
\hline
\end{tabular}

${ }^{\mathrm{z}}$ Values in parentheses indicate percentages in the total cells observed.

${ }^{y}$ Number of pollens stained with acetocarmine/number of pollens observed.

${ }^{\mathrm{x}}$ Number of pollens germinated/number of pollens observed.

${ }^{w}$ Data are from Tashiro (1984).

'Data are from M. Shigyo (unpublished data).

Table 3. Numerical data on seed set, seed germination, and seedling survival in selfed and backcrossed $1 \mathrm{~A}$ disomic addition (FFFF+1A1A) and variation of chromosome numbers in their progenies.

\begin{tabular}{|c|c|c|c|c|c|c|c|c|c|c|c|}
\hline \multirow[b]{3}{*}{ Seed parent } & \multirow{3}{*}{$\begin{array}{c}\text { Pollen } \\
\text { Parent or } \\
\text { pollination style }\end{array}$} & \multirow{3}{*}{$\begin{array}{c}\text { Ovules that } \\
\text { developed into } \\
\text { seeds }(\%)\end{array}$} & \multirow{3}{*}{$\begin{array}{c}\text { Seed } \\
\text { germination } \\
(\%) \\
\end{array}$} & \multirow{3}{*}{$\begin{array}{l}\text { Seedlings } \\
\text { survived } \\
\text { (no.) } \\
\end{array}$} & \multicolumn{7}{|c|}{ Frequency of plants } \\
\hline & & & & & \multicolumn{7}{|c|}{ Chromosomes (no.) } \\
\hline & & & & & 24 & 25 & 26 & 28 & 33 & 34 & 36 \\
\hline$\overline{\mathrm{FFFF}+1 \mathrm{~A} 1 \mathrm{~A}}$ & Selfing & $2.2(104)^{\mathrm{z}}$ & $4.8(5 / 104)^{y}$ & 3 & 0 & 0 & 0 & 0 & 1 & 1 & $\overline{1}$ \\
\hline Allium fistulosum & $\mathrm{FFFF}+1 \mathrm{~A} 1 \mathrm{~A}$ & $1.0(45)$ & $40.0(18 / 45)$ & 3 & 1 & 1 & 0 & 1 & 0 & 0 & 0 \\
\hline Allium fistulosum & Selfing $^{\mathrm{x}}$ & 36.4 (1329) & $89.5(213 / 238)$ & - & - & - & - & - & - & - & 一 \\
\hline Shallot & Selfing $^{x}$ & $21.1(316)$ & $87.0(275 / 316)$ & - & - & - & 一 & 一 & - & - & - \\
\hline
\end{tabular}

${ }^{\mathrm{z}}$ Values in parentheses indicate number of seeds produced.

${ }^{y}$ Values in parentheses indicate number of seeds germinated/number of seeds sown.

${ }^{x}$ Data are from Yamashita (1999).

${ }^{\text {w} D a t a}$ are from Shigyo et al. (1999b).

Table 4. Numerical data on leaf morphology and ascorbic acid content along with segregation data of LAP isozyme marker in selfed and backcrossed progenies of $1 \mathrm{~A}$ disomic addition (FFFF+1A1A).

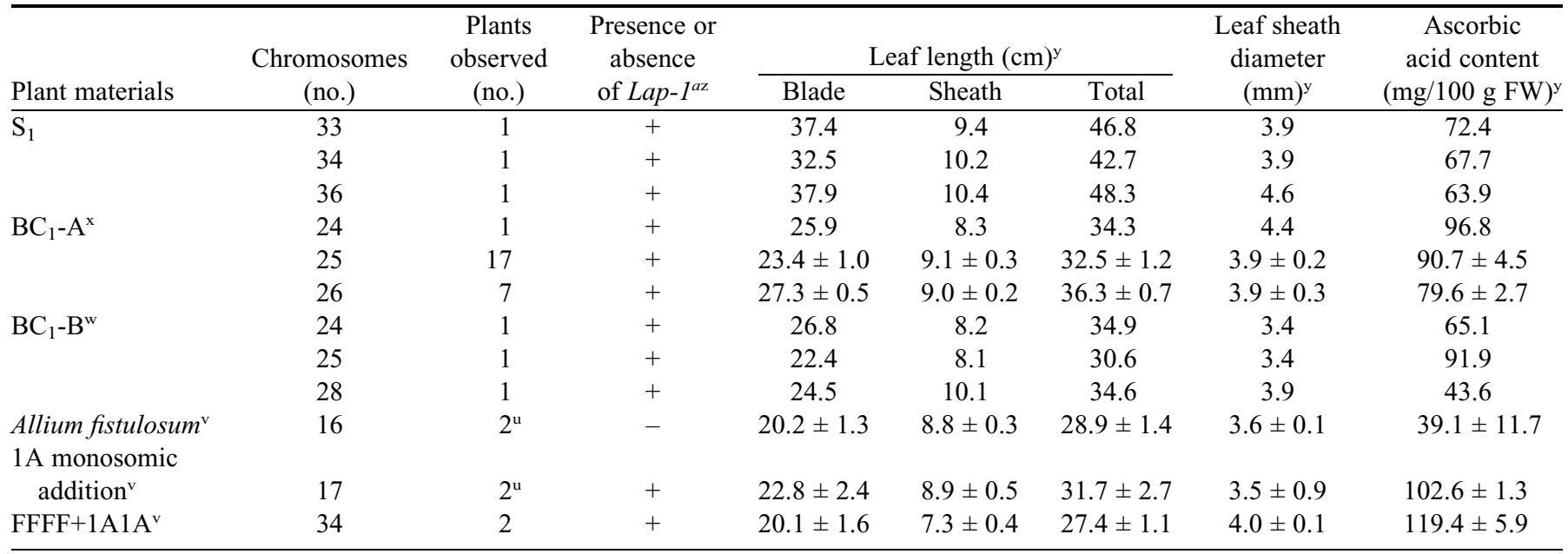

${ }^{\mathrm{z}}$ Lap $-1^{a}$ is an LAP isozyme marker specific for the chromosome 1 of shallot (see Shigyo et al., 1995). +: present, -: absent.

${ }^{y}$ Some parts of data shown with mean $\pm \mathrm{SE} ; \mathrm{n}=2-17$, determined from different plants.

'Progeny of the backcross FFFF+1A1A $(+) \times$ A. fistulosum $(\hat{\jmath})$.

wProgeny of the backcross $A$. fistulosum $(+) \times$ FFFF $+1 \mathrm{~A} 1 \mathrm{~A}\left(\mathrm{O}^{1}\right)$.

vThe footnotes indicate the plants used as controls.

uThe footnotes indicate two plants derived from one clone. 
(18 of 28) were $1 \mathrm{~A}$ monosomic additions in the triploid background of $A$. fistulosum $(2 n=3 x+1=25$; Fig. $2 \mathrm{~F})$.

MORPHOLOGICAL CHARACTERIZATION AND DETERMINATION OF ASCORBIC ACID CONTENTS IN 1A DISOMIC ADDITION PLANTS AND THEIR PROGENIES. All progenies from 1A disomic addition grew vigorously, as determined from the leaf length and leaf sheath diameter (Table 4). In ascorbic acid contents, ANOVA revealed a significant difference among plant materials at the $1 \%$ level. The ascorbic acid content of $1 \mathrm{~A}$ disomic additions $(119.4 \pm 5.9$ $\mathrm{mg} / 100 \mathrm{~g} \mathrm{FW})$ was higher than that of FF+1A $(102.6 \pm 1.3 \mathrm{mg} /$ $100 \mathrm{~g} \mathrm{FW})$. The ascorbic acid contents of $17 \mathrm{BC}_{1}-\mathrm{A}$ plants, derived from the backcross between 1A disomic addition ( $(+)$ and A. fistulosum ( $\widehat{\jmath})$, with 25 chromosomes $(90.7 \pm 4.5 \mathrm{mg} /$ $100 \mathrm{~g}$ FW) were much higher than those of the diploid A. fistulosum (39.1 $\pm 11.7 \mathrm{mg} / 100 \mathrm{~g} \mathrm{FW}$; Table 4).

\section{Discussion}

The ascorbic acid content of the $A$. fistulosum is commonly reported to be $44 \mathrm{mg} / 100 \mathrm{~g} \mathrm{FW}$ (Japan Ministry of Education, Culture, Sports, Science and Technology, 2005). The difference of the ascorbic acid content between the average of FF+1A and this previous report was about twice as much. The use of an exogenous ascorbic acid solution treatment to increase the content of endogenic ascorbic acid in A. fistulosum was reported by Inoue et al. (1998) and resulted in an increase in the ascorbic acid amounts from 46.7 to $134-144 \mathrm{mg} / 100 \mathrm{~g} \mathrm{FW}$. The ascorbic acid contents of red or yellow sweet pepper (Capsicum annuum L.) and broccoli (Brassica oleracea L. Italica group), which are considered to have a high ascorbic acid level, are 170, 150, and $120 \mathrm{mg} / 100 \mathrm{~g} \mathrm{FW}$, respectively (Japan Ministry of Education, Culture, Sports, Science and Technology, 2005). Without several cultural and postharvest treatments, FF+1A contained a substantial amount of ascorbic acid compared with several kinds of treated $A$. fistulosum and other vegetables. Therefore, $\mathrm{FF}+1 \mathrm{~A}$ may be desirable source of ascorbic acid in a diet as replaced with the existing $A$. fistulosum. It could be expected that $\mathrm{FF}+1 \mathrm{~A}$ become the breeding materials for the ascorbic acid-rich $A$. fistulosum.

A close phylogenetic relationship between $A$. fistulosum and A. cepa was demonstrated by karyotype analyses (Narayan, 1988; Vosa, 1976), crossability tests (van Raamsdonk et al., 1992), and molecular marker evaluations (Havey, 1992). On the other hand, significant differences in chromosome size and nuclear DNA content were noted between $A$. fistulosum and $A$. cepa (Havey, 2002). Furthermore, the cytogenetic behavior of chromosome parings at meiotic metaphase-I in microspores are quite different between these two species: bivalents with randomized chiasmata (ring shape) were observed in A. cepa, and those with localized chiasmata (x shape) were noted in A. fistulosum. The presence of chiasmata near the centromere of A. fistulosum could be explained if this region were largely euchromatic and, therefore, gene-rich. The presence of chiasmata near the telomere of $A$. cepa could be explained on the same grounds. A number of previous studies have shown that F1 hybrids are completely sterile. This is because of the frequent occurrences of heteromorphic bivalent and univalent chromosomes at meiotic metaphase-I. This type of interspecific hybrid usually showed more terminal (rather than localized) chiasmata (Tashiro, 1984). If genes related to favorable horticultural traits are located near the centromere in $A$. fistulosum and across the chromosomes in A. cepa, transfer of genes between these two Allium species may be difficult by conventional backcross breeding (Havey, 2002). No one has carried out a breeding program for improving A. fistulosum using $A$. серa, probably because of the poor fertility of the backcross progenies. A unique way to transfer beneficial traits from $A$. cepa to $A$. fistulosum would be via monosomic additions. We have characterized the eight different addition lines for functional chemical compounds, including flavonoids (Masuzaki et al., 2006a, 2006b; Shigyo et al., 1997b), carbohydrates (Hang et al., 2004a), and ascorbic acid. In the present study, we revealed that chromosome $1 \mathrm{~A}$ of the shallot has an important role in ascorbic acid biosynthesis in the leaf blades of the $1 \mathrm{~A}$ monosomic addition in the diploid of $A$. fistulosum. Allium fistulosum cultivar carrying an entire chromosome $1 \mathrm{~A}$ could be asexually propagated and provide enhanced ascorbic acid content to consumers.

In the present study, we successfully obtained 18 plants of the $1 \mathrm{~A}$ monosomic addition in a triploid of $A$. fistulosum from backcrossing between $1 \mathrm{~A}$ disomic addition and $A$. fistulosum. From the results of LAP isozyme and karyotype analyses, we concluded that the alien chromosomes of the $1 \mathrm{~A}$ disomic addition were transmitted after backcrossing to A. fistulosum. The presence of a pair of $1 \mathrm{~A}$ chromosomes would guarantee the transmission of this chromosome to all progenies. 1A monosomic addition in a triploid of $A$. fistulosum seems to possess favorable horticultural traits for plant shape and ascorbic acid content. Disomic additions could be useful in transferring the alien chromosomes at high frequencies to other $A$. fistulosum for use in commercial production of aneuploidy triploid varieties of $A$. fistulosum with added value.

\section{Literature Cited}

Adaniya, S. and Ardian. 1994. A new method for selecting cytochimeras by the maximum number of nucleoli per cell in Allium wakegi Araki and A. fistulosum L. Euphytica 79:5-12.

Hang, T.T.M., M. Shigyo, S. Yaguchi, N. Yamauchi, and Y. Tashiro. 2004a. Effect of single alien chromosome from shallot (Allium cepa L. Aggregatum group) on carbohydrate production in leaf blade of bunching onion (A. fistulosum L.). Genes Genet. Syst. 79:345-350.

Hang, T.T.M., M. Shigyo, N. Yamauchi, and Y. Tashiro. 2004b. Production and characterization of alien chromosome additions in shallot (Allium cepa L. Aggregatum group) carrying extra chromosome(s) of Japanese bunching onion (A. fistulosum L.). Genes Genet. Syst. 79:263-269.

Havey, M.J. 1992. Restriction enzyme analysis of the chloroplast and nuclear 45s ribosomal DNA of Allium sections Cepa and Phyllodolon (Alliaceae). Plant Syst. Evol. 183:17-31.

Havey, M.J. 2002. Genome organization in Allium, p. 59-79. In: H.D. Rabinowitch and L. Currah (eds.). Allium crop science: Recent advances. CABI, Wallingford, UK.

Inden, H. and T. Asahira. 1990. Japanese bunching onion (Allium fistulosumL.), p. 159-178. In: H.D. Rabinowitch and J.L. Brewster (eds.). Onion and allied crops, Vol. III. CRC Press, Boca Raton, FL. Inoue, K., N. Oyama, S. Kondo, Y. Hayata, and H. Yokota. 1998. Production of ascorbic acid enriched vegetables: Absorption of an L-ascorbic acid solution and the effect of storage temperature on the foliar exogenous ascorbic acid content. J. Hort. Sci. Biotechnol. $73: 681-686$.

Japan Ministry of Education, Culture, Sports, Science and Technology. 2005. Standard tables of food composition in Japan. 5th revised and enlarged ed. National Printing Bureau, Tokyo (in Japanese).

Masuzaki, S., M. Shigyo, and N. Yamauchi. 2006a. Complete assignment of structural genes involved in flavonoid biosynthesis 
influencing bulb color to individual chromosomes of shallot (Allium cepa L.). Genes Gent. Syst. 81:255-262.

Masuzaki, S., M. Shigyo, and N. Yamauchi. 2006b. Direct comparison between genomic constitution and flavonoid contents in Allium multiple alien addition lines reveals chromosomal locations of genes related to biosynthesis from dihydrokaempferol to quercetin glucosides in scaly leaf of shallot (Allium cepa L.). Theor. Appl. Genet. 112:607-617.

Murashige, T. and F. Skoog. 1962. A revised medium for rapid growth and bioassays with tobacco tissue cultures. Physiol. Plant 15:473-479.

Narayan, R.K.J. 1988. Constraints upon the organization and evolution of chromosomes in Allium. Theor. Appl. Genet. 75:319-329.

Ricroch, A., R. Yockteng, S.C. Brown, and S. Nadot. 2005. Evolution of genome size across some cultivated Allium species. Genome 48:511-520.

Roe, J.H., B.M. Mary, M.J. Desterling, and M.D. Charlote. 1948. The determination of diketo-gulonic acid, dehydro-L-ascorbic acid, and L-ascorbic acid in the same tissues extract by 2,4-dinitrophenyl hydrazine method. J. Biol. Chem. 174:201-208.

Shigyo, M., M. Iino, H. Ino, and Y. Tashiro. 1999a. Transmission rates of extra chromosomes in alien monosomic addition lines of Japanese bunching onion with extra chromosomes from shallot. J. Jpn. Soc. Hort. Sci. 68:18-22.

Shigyo, M., M. Ino, S. Isshiki, and Y. Tashiro. 1997a. Morphological characteristics of a series of alien monosomic addition lines of Japanese bunching onion (Allium fistulosum L.) with extra chromosomes from shallot (A. cepa L. Aggregatum group). Genes Genet. Syst. 72:181-186.

Shigyo, M., M. Iino, and Y. Tashiro. 1999b. Fertility of alien monosomic addition lines of Japanese bunching onion (Allium fistulosum L.) with extra chromosomes from shallot (A. cepa L. Aggregatum group). J. Jpn. Soc. Hort. Sci. 68:494-498.
Shigyo, M., Y. Tashiro, M. Iino, N. Terahara, K. Ishimaru, and S. Isshiki. 1997b. Chromosomal locations of genes related to flavonoid and anthocyanin production in leaf sheath of shallot (Allium cepa L. Aggregatum group). Genes Genet. Syst. 72:149-152.

Shigyo, M., Y. Tashiro, S. Isshiki, and S. Miyazaki. 1995. Chromosomal locations of five isozyme gene loci (Lap-1, Got-1, 6-Pgdh-2, Adh-1 and Gdh-1) in shallot (Allium cepa L. Aggregatum group). Jpn. J. Genet. 70:399-407.

Shigyo, M., Y. Tashiro, S. Isshiki, and S. Miyazaki. 1996. Establishment of a series of alien monosomic addition lines of Japanese bunching onion (Allium fistulosum L.) with extra chromosomes from shallot (A. cepa L. Aggregatum group). Genes Genet. Syst. 71:363-371.

Shigyo, M., T. Wako, A. Kojima, N. Yamauchi, and Y. Tashiro. 2003. Transmission of alien chromosomes from selfed progenies of a complete set of Allium monosomic additions: The development of a reliable method for the maintenance of a monosomic addition set. Genome 46:1098-1103.

Tashiro, Y. 1984. Cytogenetic study on the origin of Allium wakegi Araki. Bul. Fac. Agr. Saga Univ. 56:1-63 (in Japanese with English summary).

van Raamsdonk, L., W. Wietsma, and J. de Vries. 1992. Crossing experiments in Allium L. section Cepa. Bot. J. Linnean Soc. 109:293-303.

Vosa, C. 1976. Heterochromatic patterns in Allium. I. The relationship between the species of the cepa group and its allies. Heredity 36:383392.

Yakuwa, T. 2006. Welsh onion or Japanese bunching onion, p. 165 166. In: Japanese Society for Horticultural Science (ed). Horticulture in Japan 2006. Shoukadoh Publications, Kyoto, Japan.

Yamashita, K. 1999. Development of cytoplasmic male sterile lines of japanese bunching onion (Allium fistulosum L.) and shallot (A. cepa L. Aggregatum group) with cytoplasms of wild species. Kagoshima Univ., Kagoshima, Japan, PhD Thesis. 